\title{
Adult body height and childhood socioeconomic group in the Swedish population
}

\author{
A MARIA NYSTRÖM PECK AND DENNY H VÅGERÖ \\ From the Department of Social Medicine, Karolinska Institutet, Huddinge University Hospital, S-141 86, Sweden
}

SUMMARY Cross-sectional data from interviews of a sample of the Swedish population aged 16 to 74 years in 1980-81 were used to obtain information on the relation between father's socioeconomic status during the childhood of the participants and the adult body height of the latter. A difference in height between members of higher and lower socioeconomic groups was found. The difference diminished over falling age but was still noticeable among men born in the early and mid 1950s. The mean difference in height between sons of senior salaried employees and sons of unskilled workers was $2.9 \mathrm{~cm}$. The difference was less for women.

Body height among adults is dependent on genetic factors but conditions during childhood, such as nutrition and disease, do affect whether the individual realises full growth potential. ${ }^{1}$ It is very difficult to demonstrate a connection between dietary intake and growth, ${ }^{2}$ but poor nutrition is thought to be one factor in the association between poor conditions in childhood and body height demonstrated in a variety of studies. ${ }^{4-6}$ Most of these studies concern children and their social environment, and many of them use father's occupation ${ }^{7-9}$ and/or unemployment of the father ${ }^{89}$ to define poor conditions in childhood. Studies of adults have also used father's occupation during the childhood of the study subject. Such studies have indicated a relation between body height at adult age and social class in childhood. In studies where social class at adult age has been related to body height at adult age an association has also been found. ${ }^{11-13}$ For example, Marmot et al found a strong relation between height and employment grade in a study of British civil servants. The difference in mean height between the highest and lowest grades was $5.3 \mathrm{~cm} .{ }^{12}$

In their study of socioeconomic conditions in childhood and mortality and morbidity caused by coronary heart disease, Notkola et al found that, besides smoking habits, height was the most important variable related to differences in the risk of myocardial infarction in East Finland. They also found that short stature was a risk factor for coronary heart disease independent of socioeconomic position in childhood. ${ }^{10}$ The relation between body height and mortality in Norway has been studied by Waaler et al. There was a clear association between body height and total mortality. In particular there was a markedly reduced mortality from cardiovascular diseases and obstructive lung diseases with increased height. For cancer there was no correlation. ${ }^{14}$

The associations between adult body height and specific causes of death have led some authors to discuss short stature as a possible sign of general susceptibility. ${ }^{121415}$ Conditions during childhood may cause individuals to be more exposed to, or alternatively less resistant to, those factors that cause morbidity and mortality.

Sweden is sometimes mentioned as a country with none of the social inequality that leads to health differences, ${ }^{16}$ or at least it is held that these effects have diminished to a substantial degree. For instance, the Black report suggested that there are no class differences in infant mortality rates in Sweden, ${ }^{16}$ and Lindgren suggested that differences in height have been decreasing. Lindgren, in her study of schoolchildren in 1964-73, found a slight difference between social groups, but results were contradictory for boys and girls and were not statistically significant. ${ }^{17}$

In this investigation we have chosen to study the association between childhood socioeconomic group and adult body height. In a further study we intend to analyse morbidity and mortality according to socioeconomic group and body height.

\section{Material and methods}

Since 1974 the National Central Bureau of Statistics (Statistics, Sweden) has carried out annual interviews concerning living conditions, eg, health, employment, housing, social relations, and personal finance. The sample size is 8-10 000 persons a year randomly drawn from Sweden's adult population. Our study used the answers to the interviews carried out in 1980-81. We 
have used two of the approximately 150 questions, namely: 'How tall are you?'* and 'What was your father's main occupation during your childhood, ie, until you were 16 years old?' ${ }^{\dagger}$ (If the interviewee had no father or foster-father, the occupation of the mother or any other person viewed as a parent by the respondent was noted.)

The sample in 1980-81 consisted of 14757 persons aged 16 to 74 . Of these, $86.0 \%$ consented to the interview, ie, 12695 individuals (table 1). In about $2 \%$ of the interviews the answer to one or both of the questions used in this study is missing. Consequently, the results are based on 12426 interviews. A comprehensive discussion of the survey methods and the statistical precision of the results of the survey can be found elsewhere. ${ }^{18}$

The occupation of the father has been classified into seven socioeconomic groups according to a classification system used by the National Central Bureau of Statistics, Sweden since $1974 .^{20}$ The seven socioeconomic groups can be assigned to three main categories: manual workers, salaried employees, and self-employed persons. These three groups might be regarded as ranked. Within two of the main categories there is also an obvious ranking. Unskilled workers are considered to have a lower socioeconomic status than skilled workers and the salaried employees are divided into senior, intermediate, and junior. Farmers are considered separately from the other selfemployed. However, there are no obvious criteria according to which all of these seven subgroups can readily be ranked.

The mean height by five year age groups and for each sex was established for each of the seven socioeconomic groups. The sample did not differ significantly from the source population and was used as standard population in a so-called direct standardisation. In the analysis we computed age-

\footnotetext{
* 'Hur lång är Ni?'

$\dagger$ 'Vad hade Er far (fosterfar) för huvudsakligt yrke eller sysselsättning under Er uppväxttid, dvs till Ni fyllt 16 år?'
}

standardised height for the seven groups. Ninety-five percent confidence intervals were constructed using mean height and the variance of the mean.

\section{Results}

There is a strong association between body height and age group/birth cohort (figure), and the mean age varies among the socioeconomic groups in this sample (table 2). There is, however, after adjustment for age differences, a difference in height between the socioeconomic groups. The sons of unskilled workers are the shortest men in the sample with a mean height of $176.9 \mathrm{~cm}$, and the sons of senior salaried employees are the tallest, with a mean height of $179.8 \mathrm{~cm}$ (table 3 ). Among the women this difference $(1.4 \mathrm{~cm})$ is less pronounced (table 4). Men whose fathers had been senior salaried employees are significantly taller than all other men. Sons of unskilled workers and farmers are shorter than those whose fathers had been salaried employees or self-employed. For women there is a similar, but less clear, pattern.

The age-specific height for two of the groups has been analysed in more detail. The two groups are the shortest and the tallest in the sample, ie, the children of

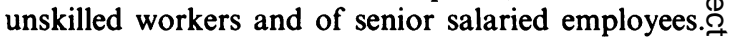
The mean height in three-year classes, calculated $\mathbb{Q}$ stepwise by adding and subtracting one 1-year cohorto at a time to smooth the curve, is presented in the figure. The difference between the two groups is larger in the male group. For both sexes it is reduced in the youngerage groups. The reduction is mainly due to a larger gain in height in the shorter group. In the birth cohorts born in 1959 and later there are no clear differences in height.

\section{Discussion}

This study is based on information collected by means of interviews. It would, of course, have been more appropriate to have had the interviewee's height measured in controlled circumstances. Other studies

Table 1 Sample size and response rate (\%)

\begin{tabular}{|c|c|c|c|c|c|c|c|}
\hline \multirow{2}{*}{$\cdot$} & \multicolumn{7}{|c|}{ Age group (years) } \\
\hline & $16-24$ & $25-34$ & $35-44$ & $45 \cdot 54$ & $55-64$ & $65-74$ & Total \\
\hline \multicolumn{8}{|l|}{ Sample size } \\
\hline $\begin{array}{l}\text { Men } \\
\text { Women }\end{array}$ & $\begin{array}{l}1218 \\
1189\end{array}$ & $\begin{array}{l}1518 \\
1446\end{array}$ & $\begin{array}{l}1414 \\
1336\end{array}$ & $\begin{array}{l}1029 \\
1123\end{array}$ & $\begin{array}{l}1147 \\
1246\end{array}$ & $\begin{array}{r}944 \\
1084\end{array}$ & $\begin{array}{l}7333 \\
7424\end{array}$ \\
\hline
\end{tabular}




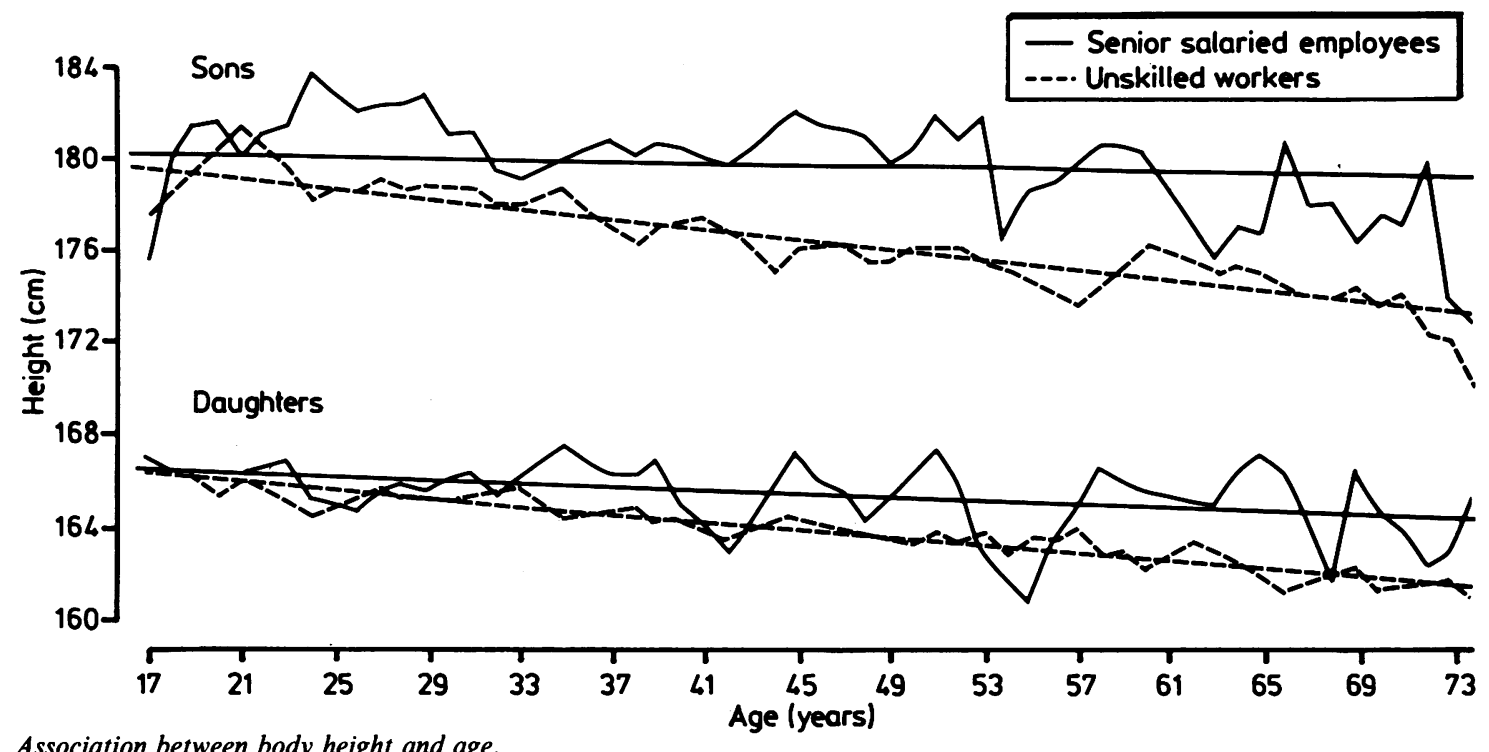

Association between body height and age.

have shown that people tend to overstate their own height slightly. Short height and low educational level were found to be linked to slightly larger overstatements. As a whole, however, the differences between actual and reported heights were very small. ${ }^{21} 22$ If people with a low educational level tend to overstate their height more than others, the observed differences in height between the socioeconomic groups that are reported here might be an underestimate of the true differences.
As far as we know, this is the first study in Sweden of the relation between adult height and socioeconomic background in childhood. In her study of schoolchildren followed up from 1964 to 1973, Lindgren found no clear differences in height between children from different social groups. She concluded that all such differences had been evened out by a larger gain in height in the lower social group than in the higher social group during the post-war period. However, there is a difference in height between the

Table 2 Mean age (years) and number of interviews by socioeconomic group according to father's occupation

\begin{tabular}{|c|c|c|c|c|}
\hline Socioeconomic group & & $\begin{array}{l}\text { Mean age } \\
\text { (years) }\end{array}$ & $\begin{array}{l}95 \% \\
\text { confidence } \\
\text { interval }\end{array}$ & $\begin{array}{l}\text { Number } \\
\text { of } \\
\text { interviews }\end{array}$ \\
\hline $\begin{array}{l}\text { Unskilled workers } \\
\text { Skilled workers }\end{array}$ & $\begin{array}{l}\mathbf{M} \\
\mathbf{F} \\
\mathbf{M} \\
\mathbf{F}\end{array}$ & $\begin{array}{l}42 \cdot 8 \\
43 \cdot 7 \\
39 \cdot 3 \\
39 \cdot 9\end{array}$ & $\begin{array}{l}42 \cdot 0-43 \cdot 6 \\
42.9-44 \cdot 5 \\
38 \cdot 4-40 \cdot 3 \\
38 \cdot 9-40 \cdot 8\end{array}$ & $\begin{array}{l}1674 \\
1683 \\
1116 \\
1192\end{array}$ \\
\hline $\begin{array}{l}\text { Salaried employees } \\
\text { Junior } \\
\text { Intermediate } \\
\text { Senior }\end{array}$ & $\begin{array}{l}\mathbf{M} \\
\mathbf{F} \\
\mathbf{M} \\
\mathbf{F} \\
\mathbf{M} \\
\mathbf{F}\end{array}$ & $\begin{array}{l}37 \cdot 6 \\
38 \cdot 1 \\
35 \cdot 5 \\
36 \cdot 6 \\
35 \cdot 4 \\
34 \cdot 8\end{array}$ & $\begin{array}{l}36 \cdot 0-39 \cdot 2 \\
36 \cdot 5-39 \cdot 6 \\
34 \cdot 2-36 \cdot 8 \\
35 \cdot 2-38.0 \\
33 \cdot 8-37 \cdot 1 \\
33 \cdot 2-36 \cdot 4\end{array}$ & $\begin{array}{l}379 \\
404 \\
583 \\
515 \\
366 \\
390\end{array}$ \\
\hline $\begin{array}{l}\text { Self-employed, farmers excluded } \\
\text { Farmers }\end{array}$ & $\begin{array}{l}\mathbf{M} \\
\mathbf{F} \\
\mathbf{M} \\
\mathbf{F}\end{array}$ & $\begin{array}{l}42 \cdot 4 \\
43 \cdot 5 \\
49 \cdot 1 \\
51 \cdot 1\end{array}$ & $\begin{array}{l}41 \cdot 2-43 \cdot 5 \\
42 \cdot 4-44.6 \\
48 \cdot 8-50 \cdot 6 \\
50 \cdot 3 \quad 51 \cdot 9\end{array}$ & $\begin{array}{r}856 \\
905 \\
1160 \\
1203\end{array}$ \\
\hline All & $\begin{array}{l}\mathbf{M} \\
\mathbf{F}\end{array}$ & $\begin{array}{l}41.9 \\
42.9\end{array}$ & $\begin{array}{l}41 \cdot 5 \cdot-42 \cdot 4 \\
42 \cdot 4-43 \cdot 3\end{array}$ & $\begin{array}{l}6134 \\
6292\end{array}$ \\
\hline
\end{tabular}

M = Male; $\quad F=$ Female 
Table 3 Mean height (cm) by socioeconomic group according to father's occupation, men, age-standardised

\begin{tabular}{|c|c|c|}
\hline Socioeconomic group & $\begin{array}{l}\text { Mean height } \\
(\mathrm{cm})\end{array}$ & $\begin{array}{l}95 \% \\
\text { confidence } \\
\text { interval }\end{array}$ \\
\hline $\begin{array}{l}\text { Unskilled workers } \\
\text { Skilled workers } \\
\text { All manual workers }\end{array}$ & $\begin{array}{l}176 \cdot 9 \\
177 \cdot 3 \\
177 \cdot 0\end{array}$ & $\begin{array}{l}176 \cdot 5-177 \cdot 2 \\
176 \cdot 8-177 \cdot 7 \\
176 \cdot 7 \cdot 177 \cdot 3\end{array}$ \\
\hline $\begin{array}{l}\text { Salaried employees } \\
\text { Junior } \\
\text { Intermediate } \\
\text { Senior } \\
\text { All }\end{array}$ & $\begin{array}{l}178 \cdot 1 \\
178 \cdot 4 \\
179 \cdot 8 \\
178 \cdot 7\end{array}$ & $\begin{array}{l}177 \cdot 3-178 \cdot 8 \\
177 \cdot 8-179 \cdot 0 \\
179 \cdot 1-180 \cdot 6 \\
178 \cdot 3-179 \cdot 1\end{array}$ \\
\hline $\begin{array}{l}\text { Self-employed, farmers excluded } \\
\text { Farmers } \\
\text { All self-employed }\end{array}$ & $\begin{array}{l}178 \cdot 0 \\
177 \cdot 1 \\
177 \cdot 5\end{array}$ & $\begin{array}{l}177 \cdot 5-178 \cdot 4 \\
176 \cdot 7-177 \cdot 4 \\
177 \cdot 2-177 \cdot 8\end{array}$ \\
\hline All men & $177 \cdot 4$ & $177 \cdot 4 \cdot 177 \cdot 5$ \\
\hline
\end{tabular}

socioeconomic groups in the corresponding birth cohorts (born in 1954-55) in our study. The sons of senior salaried employees are on average $3.9 \mathrm{~cm}$ taller than the sons of unskilled workers. The numbers are small and the differences are not statistically significant but they are concordant with the trend in the figure and with the mean values in table 3.

The literature demonstrates that children from higher social groups reach their peak height velocity earlier and become taller. It has also been said that the more well-to-do reach their adult height earlier, while others go on growing until they are well over 20 years of age. 23

In our study we have noticed that the differences in height are manifest primarily among adults and/or do not exist in the youngest age groups. The way in which our results differ from those of Lindgren with regard to the cohorts born in 1954-55 indicates that the first statement comes closer to the truth. Another explanation of the results could be differently defined social classes and/or different sampling procedures. Lindgren could not identify any clear height differences even between extreme socioeconomic groups, but she used a sample drawn from the urban population only. Our sample was drawn from the whole population born in 1896-1963, and the cohort born in 1954-55 is a subgroup of this sample. We attempted to compare the two extreme social groups in our sample within urban and rural areas respectively and for specific age groups. Because of small numbers the evidence is inconclusive, but the pattern of height differences is similar in urban and rural areas. Among

Table 4 Mean height $(\mathrm{cm})$ by socioeconomic group according to father's occupation, women, age-standardised

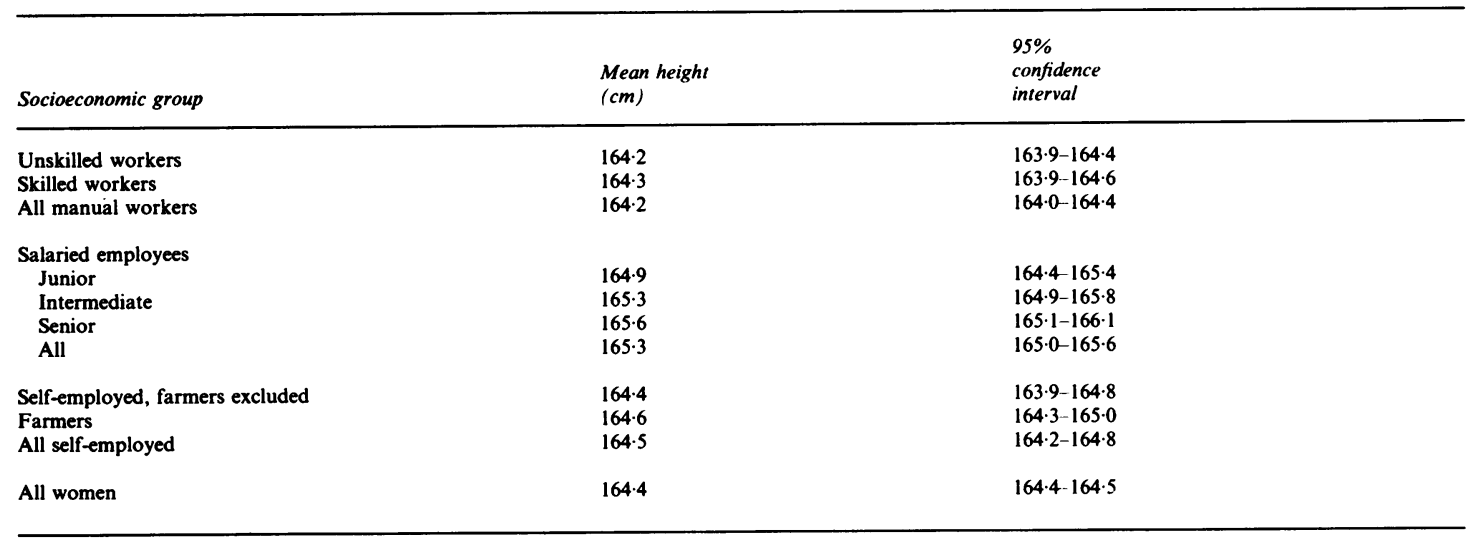


the young there may be a slight tendency for sons and daughters of unskilled workers to be more disadvantaged in rural areas.

From the regression line in the figure it can be noted that there is an increase in mean height of about $2 \mathrm{~mm} / \mathrm{year}$ among the sons of senior salaried employees and of about $4 \mathrm{~mm} /$ year among the daughters. The increase in mean height is larger among the sons and daughters of unskilled workers, about 11 and $8 \mathrm{~mm}$ respectively. This means that height differences between the two groups decrease with time. This trend is well in line with Lindgren's suggestion that the height differences between social groups diminish with time due to a greater height gain in the lower classes. Whether or not this process has ceased we cannot definitely say.

In 1955 health insurance was made compulsory, and since then a working class wage earner has been able to stay at home from work without a major loss of weekly family income. We can only speculate as to the importance of this and other health and social reforms undertaken in the post-war period.

Because of the cross-sectional design of our study it is not possible to separate effects of ageing from birth cohort effects. Thus, we cannot assess adequately here the relative importance of living conditions in childhood gradually becoming more equal $v$ the effects of differentiated ageing processes between social groups. We still conclude, however, that living conditions during childhood affect adult height.

Finally, we assumed that there are no genetic differences between the social groups which could affect growth. The association between upward social mobility and height has been studied with the assumption that height causes mobility, ${ }^{24}{ }^{25}$ but we have had difficulty in controlling the effect of living conditions during childhood as a possible confounder in such associations. This is also true in studies of siblings. We could not exclude the possibility of a connection between social mobility and height in Sweden but consider this to be a less plausible explanation of our results. We hope, however, to go into this matter further at a later stage

\section{References}

${ }^{1}$ Carter CO, Marshall WA. The genetics of adult stature. In: Human growth, ed Falkner F, Tanner JM. New York, 1978.

${ }^{2}$ Hackett AF, Rugg-Gunn AJ, Appleton DR, Parkin JM, Eastoe JE. A two-year longitudinal study of dietary intake in relation to the growth of 405 English children initially aged 11-12 years. Ann Hum Biol 1984; 11: 545-53.

${ }^{3}$ Zee P, DeLeon M, Roberson P, Chen C-H. Nutritional improvement of poor urban pre-school children. A comparison 1977-1983. JAMA 1985; 253: 3269-72.
${ }^{4}$ Bogin B, MacVean RB. The relationship of socioeconomic status and sex to body size, skeletal maturation, and cognitive status of Guatemala City school children. Child Development 1983; 54: 115-28.

5 Johnston FE, Low SM, Baess de Y, MacVean RB. Growth status of disadvantaged urban Guatemalan children of a resettled community. Am J Physical Anthropology 1985; 68: 215-24.

${ }^{6}$ Silva PA, Birkbeck J, Williams S. Some factors influencing the stature of 7 year old children. A report from the Dunedin Multidisciplinary Health and Development Research Unit. Austr Paediatr J 1985; 21: 27-30.

${ }^{7}$ Billewicz WZ, Thomson AM, Fellowes HM. A longitudinal study of growth in Newcastle upon Tyne adolescents. Ann Hum Biol 1983; 10: 125-33.

${ }^{8}$ Mascie-Taylor CGN. Regional and social analysis of height in a contemporary British sample. Ann Hum Biol 1985; 12: 315-24.

${ }^{9}$ Rona RJ, Swan AV, Altman DG. Social factors and height of primary school children in England and Scotland. $J$ Epidemiol Comm Health 1978; 32: 147-54.

${ }^{10}$ Notkola V, Punsar S, Karvonen MJ, Haapakoski J. Socioeconomic conditions in childhood and mortality and morbidity caused by coronary heart disease in adulthood in rural Finland. Soc Sci Med 1985; 21: 517-23.

${ }^{11}$ Driver ED, Driver AE. Social class and height and weight in metropolitan Madras. Social Biology 1983; 30: 189204.

12 Marmot MG, Shipley MJ, Rose G. Inequalities in deathspecific explanations of a general pattern? The Lancet 1984; i: 1003-6.

${ }^{13}$ Fehily AM, Phillips KM, Yarnell JWG. Diet, smoking, social class, and body mass index in the Caerphilly heart disease study. Am J Clin Nutr' 1984; 40: 827-33.

${ }^{14}$ Waaler HTH. Height, weight and mortality. The Norwegian experience. Acta Med Scand 1984, Suppl 679.

15 Barker DJP, Osmond C. Infant mortality, childhood, nutrition, and ischaemic heart disease in England and Wales. The Lancet 1986; i: 1077-81.

16 Black D, Morris JN, Smith C, Townsend P. Inequalities in Health. Report of a working party. London: DHSS, 1980; 139.

${ }^{17}$ Lindgren G. Height, weight and menarche in Sweden urban school children in relation to socioeconomic and regional factors. Ann Hum Biol 1976; 3: 501-28.

${ }^{18}$ Social Report on Inequality in Sweden. Distribution of welfare at the end of the 1970s Official Statistics of Sweden, NCBS, Stockholm 1981. (Living Conditions, No. 27).

${ }^{19}$ Levnadsförhållanden, Appendix 6. SOS Statistiska centralbyrån. Stockholm, 1983.

${ }^{20}$ Socioeconomisk indelning (SEI), Meddelande i samordingsfrågor 1982:4, Statistiska centralbyrån, Stockholm, 1983.

${ }^{21}$ Stewart AL. The reliability and validity of self-reported weight and height. J Chron Dis 1982; 33: 295-309.

22 Palta M, Prineas RJ, Berman R, Hannan P. Comparison of self-reported and measured height and weight. $A m J$ Epidemiol 1982; 115: 223-30.

${ }^{23}$ Hulanicka B, Kotlarz K. The final phase of growth in height. Ann Hum Biol 1983; 10: 429-34.

${ }^{24}$ Schumacher $A$, Knussmann $R$. Are the differences in stature between social classes a modification or an assortment effect? J Human Evolution 1979; 8: 809-12.

25 Bielicki T. Body height and upward social mobility. Ann Hum Biol 1983; 10: 403-8. 